also important to develop some feeling for the strategy of how vaccination could be used to contain outbreaks of foot and mouth disease. Much will depend on the improvement of vaccines and of techniques which the years ahead are certain to bring. Already there is a vaccine against three strains of the virus which costs no more than the univalent preparations available a decade ago. The authorities should seek more deliberately than in the past to exploit the new opportunities which are arising. There is also a strong case for believing that progress would be faster than it is if research were prosecuted more urgently. The epidemiology of foot and mouth disease cries out for more serious attention than it has so far received, and this is only one of the directions in which efforts should be encouraged.

There is also a strong case for a better co-ordination of national policies towards foot and mouth disease, especially in tightly knit and intensively farmed regions such as Europe, for foot and mouth virus has no respect for national frontiers. Above all, it is necessary somehow to throw off catatonic acceptance that foot and mouth disease can only be countered by slaughtering. There is too much similarity for comfort between the funeral pyres on British farms in recent weeks and the sacrificial flames with which the ancients sought to keep away evil spirits.

\section{Hemispheric Queue}

THERe is rough justice in the fact that British people wanting to emigrate to America in the next three years will find themselves at the end of the queue. What Congress intended when it liberalized the American immigration laws in 1965 was to end the system of choosing aliens on a basis of their country of origin, northern Europeans preferred, that had given offence around the world since 1921. The new law says simply, in President Johnson's words, "that those wishing to emigrate to America shall be admitted on the basis of their skills and their close relationship to those already here". The old British quota--65,361 a year-the largest allotted to any country-was based on the fact that the British were the original settlers whose descendants formed the dominant ethnic group in isolationist post-world War I America. Not only did this generous quota mean that the British could emigrate to America on the spur of the moment, but also that about 35,000 visas a year were left unused.

But good intentions can backfire. The first big shock came when Congress realized that its new immigration law was a positive invitation to skilled and professional people from underdeveloped countries to join the brain drain. In the transition period between October 1965 when the bill was passed and next July, when it comes into full effect, unused portions of national quotas were transferred to countries with long waiting lists. Immediately the flow of doctors, scientists and engineers from Asia, Africa and South America jumped dramatically (the number of immigrant visas given to Asian professionals nearly tripled between 1965 and 1966 ).

Now July 1968 is approaching; that is the date on which national quotas expire completely and Britain loses its special privilege of easy entry for ever. Suddenly people have taken a look at the waiting list which is accumulating in the State Department files in Washington and have discovered that the category of so-called "third preference" immigrants (professional, as distinct from technically skilled) is filled for the next three years. And there are few, if any, British, German, Irish or Scandinavian names among the 48,000 on the list.

Mr William Douglas of Careers Incorporated thinks that the new restrictions could put such recruiters for American industry as himself out of business. Dr F. E. Jones of the Working Group on Migration prefers to wait and see. So does the consular section of the American Embassy in London. The law, like any other, has its loopholes. It is certainly possible to go to work in America without getting an immigrant visa: there are various forms of permits allowing for exchanges, training programmes and special exceptions in the national interest. At this point it would be rash to say that American universities or industries could not find a visa for the British apple of their eye. What it is safe to promise, however, is that idle daydreams of "perhaps I'll emigrate" will have to stop. Professional men will have to take a firm decision well in advance to go to America or sit back and wait for the exceptional job offer from the company that is willing and able (no one is sure if and how this will be done) to pull strings to get round the new law.

As it stands, the Immigration Act allows 17,000 visas a year for emigrants in the professional class from the eastern hemisphere. (Canadians and Latin Americans are allowed in more freely.) Visas will be awarded on a first-come, first-served basis, with members of each preference class competing with equality for the limited number of places, regardless of their country of origin. The actual numbers of professionals taken may be smaller still, as wives and children will be given visas from this list. There is, moreover, a ceiling of 20,000 on emigration of all kinds, other than relatives, from any one country.

The American Embassy's advice to any intending British emigrants is to apply before the end of next June. After that, really desperate measures might be necessary: emigrating to Canada first, or marrying an American. Helping Britain to stem its brain drain was the last thing Congress had in mind when it tackled this controversial problem in 1965. Yet this thought might be consolation to any Britons who are unable to move across the Atlantic in the next few years. They might also be glad to be relieved of the Anglo-Saxon's guilt of lolling in and out of America at will while countless southern Europeans and Orientals waited outside in vain.

Conceivably Congress could amend the law. Some American companies--those along Route 128 near Boston, for example-are worried about losing their British recruits. And some congressmen are worried about the unexpectedly weak demands for visas in the close-relative categories. The House of Representatives Judiciary Committee may soon hold hearings about the problem. But if any amendment were to be made, priority would probably be given to stemming the drain from underdeveloped countries. Any attempt then to bend the law to allow more British in would smack of the old favouritism, quite apart from the outcry it would start in this country. 